\title{
Study on corrosion behavior of X80 steel under stripping coating by sulfate reducing bacteria
}

\author{
Yan-Yu Cui, Yong-Xiang Qin*, Qing-Miao Ding and Yu-Ning Gao
}

\begin{abstract}
Background: At present, microorganism has been considered as important factors that threaten to buried pipelines with disbonded coatings. Aiming at the problem of unknown corrosion mechanism of sulfate-reducing bacteria (SRB), a series of studies have been carried out in this paper. Spectrophotometer and fluorescent labeling technology are used to study the growth and attachment of SRB in the simulated soil solution. The corrosion behavior of X80 pipeline steel with or without SRB was researched by electrochemical methods such as open circuit potential, dynamic potential polarization curve, and electrochemical impedance spectroscopy. The microscopic morphology of the corrosion products on the surface was observed with a scanning electron microscope (SEM), and the element content of the corrosion products on the surface of the sample after corrosion was observed using X-ray energy spectrum (EDS) analysis.

Results: The results showed that the growth and reproduction of SRB caused the $\mathrm{pH}$ of the soil simulated solution to increase, which may promote the corrosion of X80 steel. In addition, the cathode reaction of X80 steel in a sterile environment is the reduction of $\mathrm{H}^{+}$, and the main corrosion product is iron oxide. When the soil simulation solution contains SRB, the cathodic reaction is controlled by both $\mathrm{H}^{+}$reduction and sulfide depolarization reactions, and FeS appears in the corrosion products.

Conclusion: Although the life cycle of SRB is only about 14 days, the corrosion of X80 steel is greatly promoted by SRB, and even causes corrosion perforation, which will bring huge economic losses and serious safety hazards.
\end{abstract}

Keywords: Sulfate reducing bacteria (SRB), Microbial corrosion, X80 steel, Electrochemistry

\section{Background}

Microbiologically influenced corrosion (MIC) refers to microbial life activities that directly or indirectly promote the metal destruction caused by the corrosion process [1-5]. They can be found in various fields such as soil, machinery, oil fields and seawater. MIC is basically caused by bacteria, which is essentially electrochemical corrosion [6-12]. Generally, anti-corrosion coatings and cathodic protection are used in combination to deal

\footnotetext{
* Correspondence: 550462668@qq.com

College of Airport, Civil Aviation University of China, Tianjin 300300, P. R. China
}

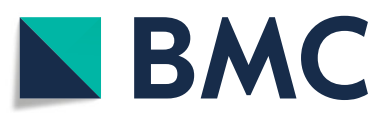

(0) The Author(s). 2021 Open Access This article is licensed under a Creative Commons Attribution 4.0 International License, which permits use, sharing, adaptation, distribution and reproduction in any medium or format, as long as you give appropriate credit to the original author(s) and the source, provide a link to the Creative Commons licence, and indicate if changes were made. The images or other third party material in this article are included in the article's Creative Commons licence, unless indicated otherwise in a credit line to the material. If material is not included in the article's Creative Commons licence and your intended use is not permitted by statutory regulation or exceeds the permitted use, you will need to obtain permission directly from the copyright holder. To view a copy of this licence, visit http://creativecommons.org/licenses/by/4.0/. The Creative Commons Public Domain Dedication waiver (http://creativecommons.org/publicdomain/zero/1.0/) applies to the data made available in this article, unless otherwise stated in a credit line to the data.

with external corrosion of metal materials such as underground pipelines and oil storage tanks. This measure slowed the corrosion rate to a certain extent, but the corrosion problem still exists. In addition, if the anticorrosion layer has defects such as shedding, the corrosion rate of the buried pipeline will be further accelerated [3, 13-15]. According to investigations, sulfate reducing bacteria, iron bacteria, iron oxidizing bacteria, and sulfur oxidizing bacteria have a great influence on metal corrosion, and SRB is considered to be one of the most influential microorganisms [16-19]. At present, national and international researchers have done many studies about SRB corrosion. Venzlaff et al. [20] used 
Table 1 Chemical composition of X80 steel (wt\%)

\begin{tabular}{|c|c|c|c|c|c|c|c|c|c|c|c|}
\hline & $\mathrm{Si}$ & $\mathrm{Mn}$ & $\mathbf{P}$ & $S$ & $\mathrm{Cr}$ & $\mathrm{Ni}$ & $\mathrm{Ti}$ & $\mathrm{Nb}$ & $v$ & Mo & $\mathrm{Fe}$ \\
\hline 063 & 0.28 & 1.83 & 0.011 & 0.0006 & 0.03 & 0.03 & 0.016 & 0.061 & 0.059 & 0.22 & For balance \\
\hline
\end{tabular}

potential dynamics polarization measurement and found that the electrons released by the anode dissolution are directly transferred to the specific protein in the sulfate reduction site of the cell through the conductive ferrous sulfide to reduce the sulfate. This conclusion is consistent with the BCSR (Biocatalytic cathodic sulfate reduction) theory proposed by Enning [21]. Wikiel, Dong and Castaneda [19, 22, 23] believe that the multi-anisotropy of biofilm on the metal surface, the solution enters the bottom of the biofilm through the porous structure of the biofilm and directly contacts the metal, which makes the environment of the metal vary and local corrosion is more likely to occur. Brenda and Washizu [24, 25] believe that biofilm has a catalytic effect, which can increase the cathode current density and accelerate the self-passivation of metal surfaces.

However, due to the diversity of SRB and the complexity of its metabolism, the corrosion mechanism of SRB is still inconclusive. In addition, there are few reports on the effect of SRB corrosion on the metal substrate under the peeling coating. Therefore, it has practical engineering significance and application value to carry out the corrosion research of SRB in complex environment. Therefore, in order to provide a certain theoretical basis and data support for the safe operation of the pipeline, a series of technical meanswere used to study the influence of SRB on the corrosion behavior of X80 steel under peeling coating.

\section{Methods}

\section{Sample preparation}

The copper wire was welded to the back of the sample, and the side and welding surface were sealed with epoxy resin. The working surface was polished to the mirror surface with a series of emery paper (coarseness between 320 and 2000 mesh), and then distilled water, ethanol and acetone were used to wash it. The chemical composition (mass fraction) of X80 pipeline steel is shown in Table 1.

\section{Experimental medium}

The soil near the X80 pipeline being used in southwestern China was put into a drying box to air dry to remove debris, and then it was dried for $10 \mathrm{~h}$ to remove moisture in an oven at $120^{\circ} \mathrm{C}$. The dried soil and deionized water are mixed with a mass ratio of $1: 5$, and the titration test is performed by centrifugation [26]. The chemical composition and content of the soil are shown in Table 2. The soil simulation solution is prepared with deionized water, and nitrogen is filled into the solution to exhaust oxygen. Subsequently, it was placed in an autoclave ( $403 \mathrm{~K})$ for about thirty minutes to kill the original microorganisms.

\section{Activation culture and inoculation of sulfate reducing bacteria}

The Postgate medium $(0.52 \mathrm{~g})$, D-sodium lactate $(0.11 \mathrm{~g})$, and distilled water $(100 \mathrm{~mL})$ were measured and placed in a sterile Erlenmeyer flask, after which $5 \mathrm{~mol} / \mathrm{L} \mathrm{NaOH}$ was used to adjust the $\mathrm{pH}$ of the solution. The configured medium is sterilized in an autoclave, and then it is placed on an ultra-clean workbench to cool to room temperature, and the UV lamp is always turned on during the cooling process. Among them, the components of Postgate medium are divided into: Yeast extract $1.0 \mathrm{~g} / \mathrm{L}$, Sodium sulfate $\left(\mathrm{Na}_{2} \mathrm{SO}_{4}\right) 3.5 \mathrm{~g} / \mathrm{L}$ 、 Magnesium chloride hexahydrate $\left(\mathrm{MgCl}_{2} \cdot 6 \mathrm{H}_{2} \mathrm{O}\right) 2.0 \mathrm{~g} / \mathrm{L}$ 、Ascorbic $\quad \operatorname{acid}\left(\mathrm{C}_{6} \mathrm{H}_{8} \mathrm{O}_{6}\right) 0.1 \mathrm{~g} /$ $\mathrm{L} 、$ Ammonium chloride $\left(\mathrm{NH}_{4} \mathrm{Cl}\right) 1.0 \mathrm{~g} / \mathrm{L}$ 、 Dipotassium phosphate $\left(\mathrm{K}_{2} \mathrm{HPO}_{4}\right) 0.5 \mathrm{~g} / \mathrm{L}$ 、 Calcium chloride $\left(\mathrm{CaCl}_{2}\right) 0.05$ $\mathrm{g} / \mathrm{L} 、$ Ferrous sulfate heptahydrate $\left(\mathrm{FeSO}_{4} \cdot 7 \mathrm{H}_{2} \mathrm{O}\right) 0.5 \mathrm{~g} /$ $\mathrm{L} 、$ Sodium thioglycolate $\left(\mathrm{C}_{2} \mathrm{H}_{3} \mathrm{NaO}_{2} \mathrm{~S}\right) 0.1 \mathrm{~g} / \mathrm{L}$.

The purebred SRB was taken out of the refrigerator to thaw, and then $30 \mathrm{~mL}$ of pure bacterial solution (including glycerol) was removed with a pipette and added to the prepared liquid medium $(100 \mathrm{~mL})$ [27]. The inoculated medium was placed in a constant temperature biochemical incubator at $30^{\circ} \mathrm{C}$ for cultivation, and the color change of the liquid medium was continuously observed. If it turns black completely, it indicates that the cultured SRB has biological activity. The experiment is divided into two groups: (a) the bacteria experimental group inoculated with SRB and (b) the sterile control group not inoculated with SRB. For the experimental group with bacteria, the cultured SRB solution $(50 \mathrm{~mL})$ and the simulated soil solution $(950 \mathrm{~mL})$ were mixed. For the sterile control group, deionized water $50(\mathrm{~mL})$ and simulated soil solution $(950 \mathrm{~mL})$ were mixed [26].

\section{Electrochemical experiment}

The epoxy primer was thermally sprayed onto the bottom plate of the experimental device to simulate the peeling of the coating. The schematic diagram of the experimental test device is shown in Fig. 1, where the peeling height of the coating is $1 \mathrm{~mm}$. The electrochemical

Table 2 Chemical composition of soil solution

\begin{tabular}{lcccc}
\hline $\mathbf{H}_{\mathbf{2}} \mathbf{O} / \mathbf{m L}$ & $\mathrm{Na}_{\mathbf{2}} \mathrm{CO}_{\mathbf{3}} / \mathbf{g}$ & $\mathbf{N a C l} / \mathbf{g}$ & $\mathbf{N a}_{\mathbf{2}} \mathbf{S O}_{\mathbf{4}} / \mathbf{g}$ & $\mathbf{N a H C O}_{3} / \mathbf{g}$ \\
\hline 1000 & 0.16 & 0.5125 & 0.1712 & 0.0865 \\
\hline
\end{tabular}




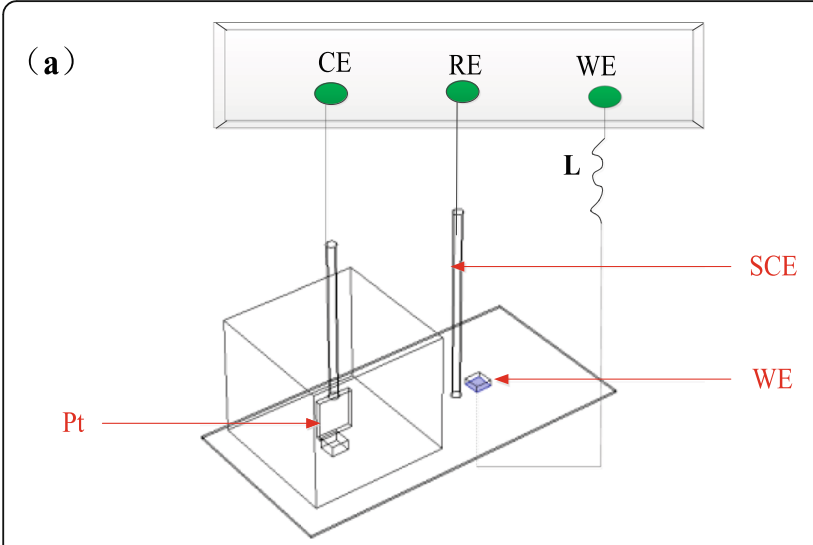

(b)

Fig. 1 Schematic of experimental set-up: (a) Three-dimensional; (b) Two-dimensional

experiment uses a three-electrode test system, the electrochemical workstation model is CHI660D, in which X80 pipeline steel is used as the working electrode, the saturated calomel electrode is used as the reference electrode, and the Pt electrode is used as the auxiliary electrode. Electrochemical experiments mainly include open circuit potential (OCP), dynamic potential polarization curve, alternating current impedance (EIS) test [6]. First, the open circuit potential of the working electrode is tested, and then after it stabilizes, the electrokinetic polarization curve and EIS are tested. The scan rate of the polarization curve is $0.1 \mathrm{mV} / \mathrm{s}$, the scan range is Eocp $\pm 250 \mathrm{mV}$, and the scan rate of EIS is $0.5 \mathrm{mV} / \mathrm{s}$, the test frequency range is $10^{-2} \sim 10^{6}$, and the AC excitation signal is a $10 \mathrm{mV}$ sine wave.

\section{Soak experiment}

The prepared electrode was immersed in the experimental device for 10 days, and then it was fixed with $2 \%$ glutaraldehyde phosphate buffer for about $5 \mathrm{~h}$. After the fixation is completed, rinse with sterile saline and use alcohol of $25,50,75$, and $100 \%$ volume fraction to dehydrate about $10 \mathrm{~min}$ [27]. After dehydration, use the model EMS 850 critical point dryer for drying. After dehydration was completed, we used the model EMS 850 critical point dryer for drying. Then use the environmental field SEM of model KYKY-EM6X00 to observe the micro-morphology of the corrosion products on the surface of the sample, and EDS to analysis the elemental of the corrosion products on the surface. The applied SEM and EDS working parameters are as follows: the imaging method was secondary electron imaging (SEI), acceleration voltage was $15,000 \mathrm{~V}$, working distance was $7500 \mu \mathrm{m}$ and the emission current was $159 \mu \mathrm{A}$. Furthermore, the EDS system was energy dispersive type and the beam current was $40 \mathrm{nA}$.

\section{Weightlessness experiment}

First, the sample was weighed with a high-precision electronic analytical balance model FA2005N. After
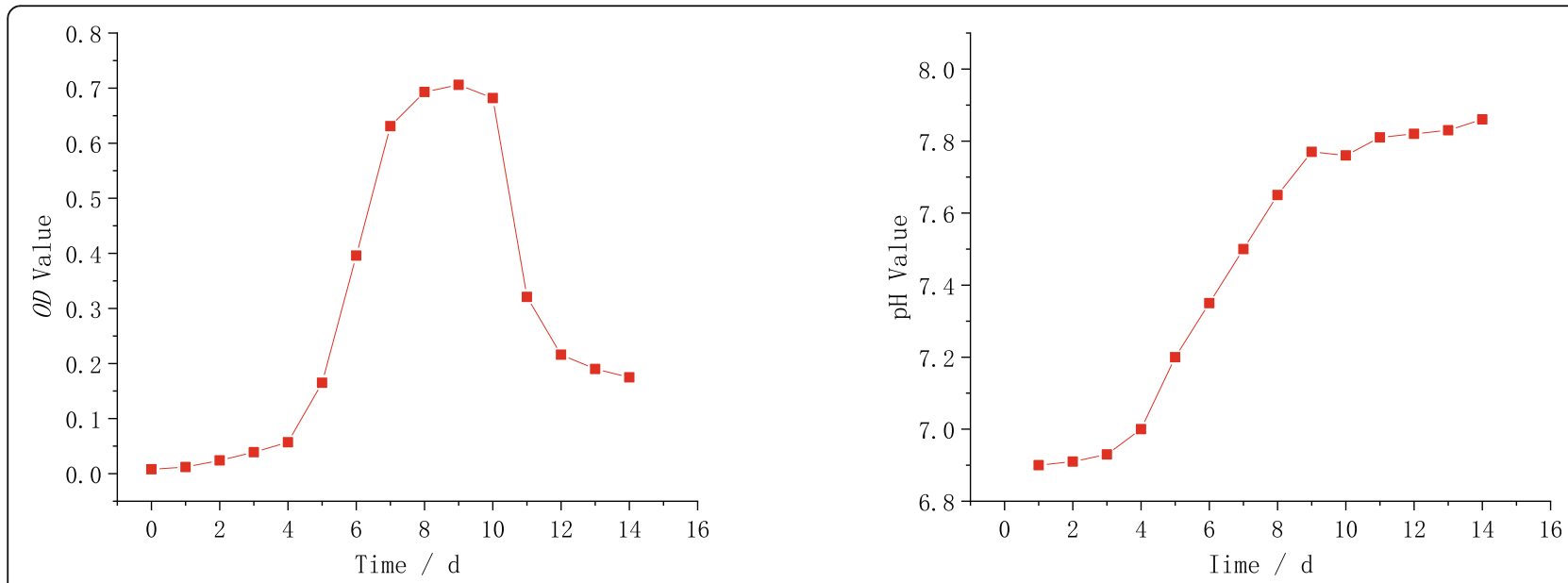

Fig. 2 Variations of $O D$ value and $\mathrm{pH}$ value with time: (a) $O D$ value; (b) $\mathrm{pH}$ value 
the sample was soaked, it was rinsed with deionized water and immersed in a rust removal solution (500 $\mathrm{mL}$ concentrated hydrochloric acid $+500 \mathrm{~mL}$ distilled water $+3.5 \mathrm{~g}$ hexamethylenetetramine) at room temperature for $10 \mathrm{~min}$ to remove surface corrosion product. After the rust removal is complete, the sample is cleaned with deionized water and absolute ethanol, and then completely dried (the difference between the two measurements is within $0.0002 \mathrm{~g}$ can be considered sufficiently dry), and finally weighed again. The corrosion rate is calculated.

\section{Result}

\section{Growth of SRB}

An 754PC ultraviolet spectrophotometer was used to measure the optical density $(O D)$ value of the solution after X80 was immersed in the soil for different days [28], the measurement results are shown in Fig. 2. It can be seen from Fig. 2 (a) that SRB are the adaptation period from the first day to the forth. This stage shows that SRB do not rapidly multiply and die after entering the new environment (soil simulation solution) from the culture medium and its number is relatively stable overall. From the forth days to the eighth, SRB enter logarithmic growth phase, and the growth rate of SRB are the fastest in this phase. From the eighth days to the tenth, SRB enter stable growth period, and the number of SRB reached the maximum. From the thirteenth days to the fourteenth, SRB enters the residual stage, in which the number of SRB is relatively stable, and the total number remains at a low level. In addition, hydrogen ions are continuously consumed during the growth and

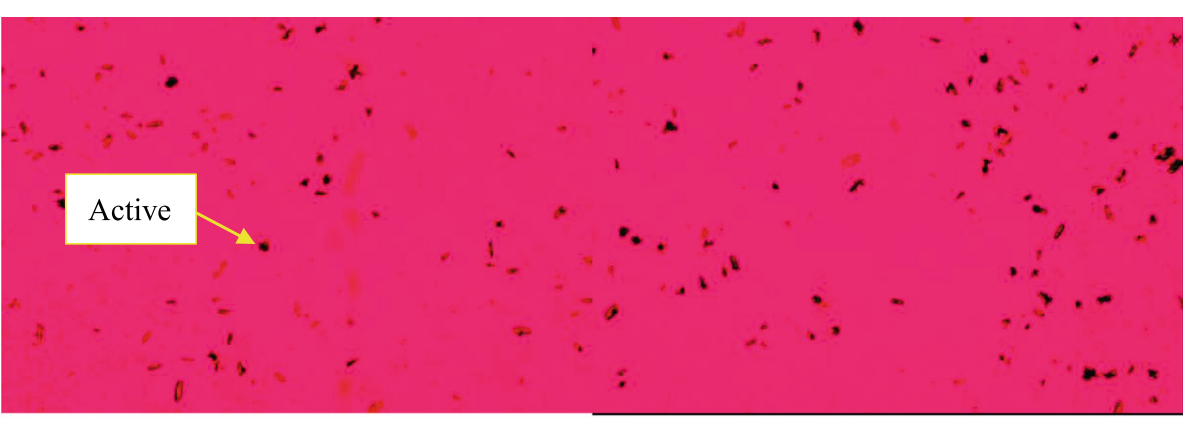

(a) 3d

(b) $6 \mathrm{~d}$

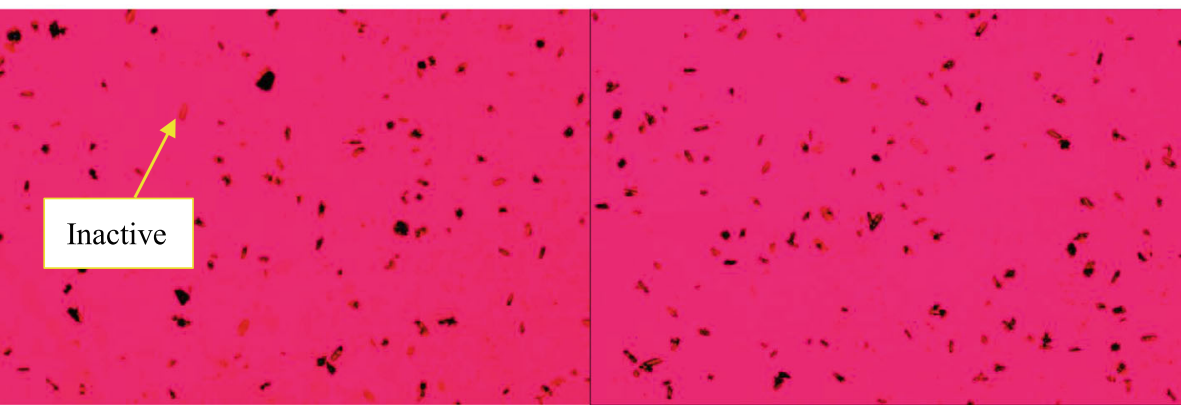

(c) $9 \mathrm{~d}$

(d) $12 \mathrm{~d}$

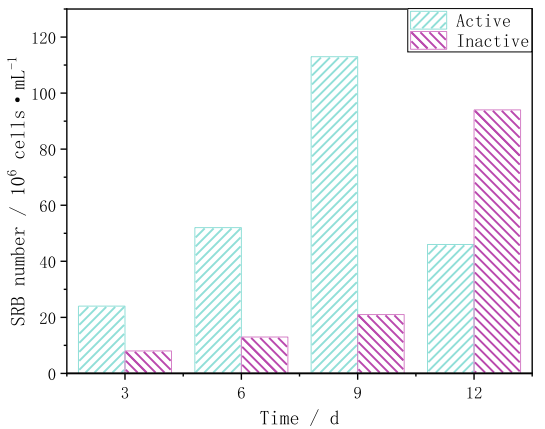

(e) Quantity statistics

Fig. 3 The number of SRB on the surface changes with the immersion time: (a) 3d; (b)6d; (c) 9d; (d) 12d; (e) Quantity statistics 


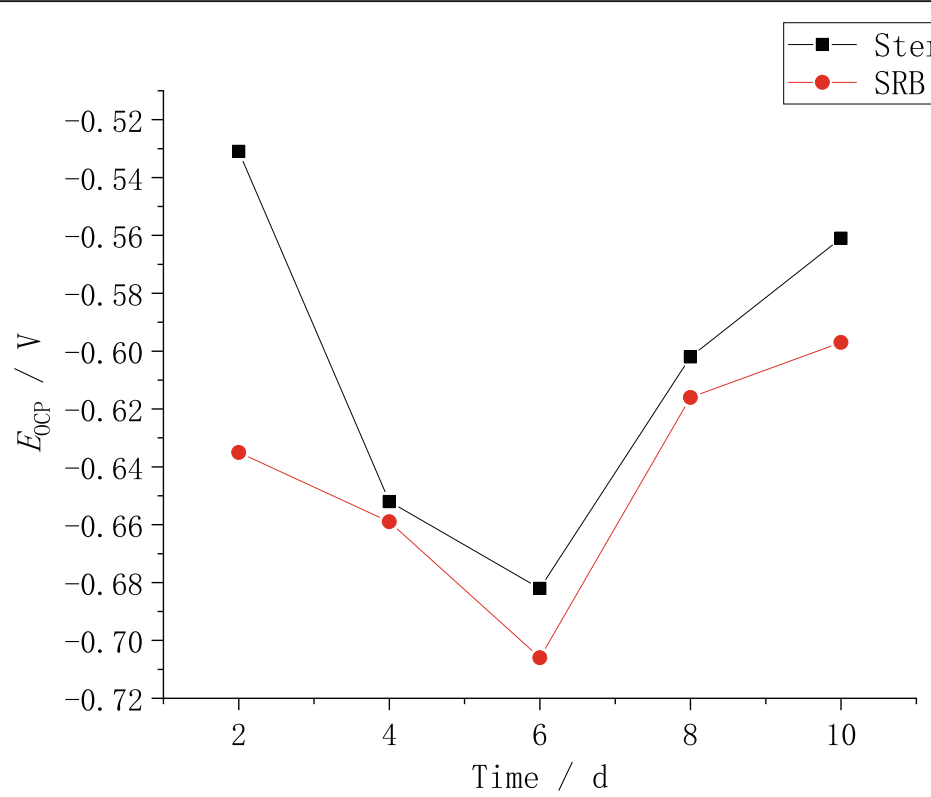

Fig. 4 Open circuit potential of X80 steel in bacteria and sterile environment

reproduction of SRB, which leads to a continuous increase in the $\mathrm{pH}$ of the solution. This conclusion is consistent with the experimental results in Fig. 2 (b).

In addition, acridine orange was used to fluorescently label the SRB on the sample surface and it can specifically bind to nucleic acid substances in cells after contact with bacteria. At the same time, Imagepro Plus software was used to count the number of SRB attached to the sample surface and the results are shown in Fig. 3 [26] (the magnification is 500 times). It can be seen from Fig. 3 that the amount of
SRB attached to the surface of the sample increases with the increase of the soaking time. At the third day, the amount of SRB attached to the surface of the sample was small and partially inactivated. At the sixth day, the amount of SRB adhered to the surface of the sample increased, and the number in the inactivated state decreased. At the ninth day, the amount of SRB adhesion on the surface of the sample significantly increased. At the twelfth day, the amount of SRB adhesion on the surface of the sample continued to increase, but most of them are in an inactive state.

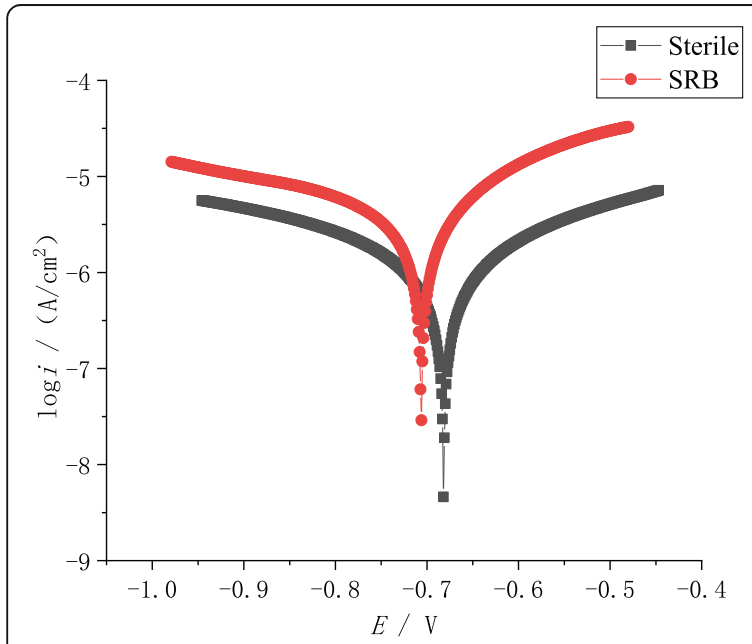

(a) $5 d$

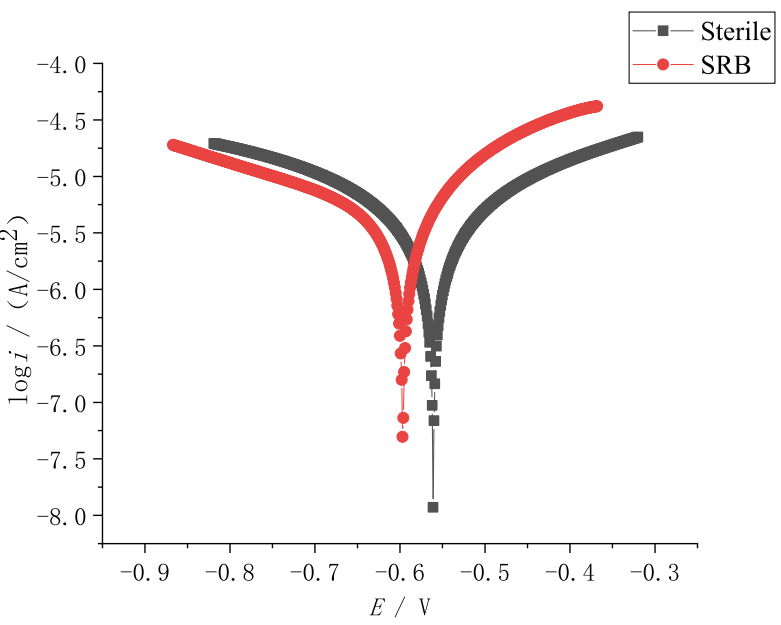

(b) 10d

Fig. 5 Potential polarization curve of X80 steel in sterile and bacteria soil simulation solution 
Table 3 Fitting results of polarization curves in sterile and bacteria soil simulated solutions

\begin{tabular}{|c|c|c|c|c|c|c|}
\hline Environment & $\begin{array}{l}\text { Time } \\
\text { (d) }\end{array}$ & $\begin{array}{l}E_{\text {corr }} \\
(\mathrm{V})\end{array}$ & $\begin{array}{l}i_{\text {corr }} \\
\left(\mu \mathrm{A} / \mathrm{cm}^{2}\right)\end{array}$ & $\begin{array}{l}\beta_{\mathrm{a}} \\
\left(\mathrm{mV} \cdot \mathrm{dec}^{-1}\right)\end{array}$ & $\begin{array}{l}\beta_{\mathrm{c}} \\
\left(\mathrm{mV} \cdot \mathrm{dec}^{-1}\right)\end{array}$ & $\beta_{\mathrm{a}} / \beta_{\mathrm{c}}$ \\
\hline \multirow[t]{2}{*}{ Sterile } & 5 & -0.682 & 1.064 & 727.0 & 651.4 & 1.12 \\
\hline & 10 & -0.602 & 1.535 & 711.9 & 669.4 & 1.06 \\
\hline \multirow[t]{2}{*}{ SRB } & 5 & -0.647 & 7.922 & 735.4 & 659.1 & 1.16 \\
\hline & 10 & -0.552 & 10.95 & 719.5 & 663.1 & 1.09 \\
\hline
\end{tabular}

Effect of SRB on the electrochemical behavior of X80 steel The open circuit potential $\left(E_{O C P}\right)$ of X80 pipeline steel in bacteria and sterile soil simulation solution over time is shown in Fig. 4. It can be found from Fig. 4 that the open circuit potential of X80 steel changes with time in the same way in the soil solution containing SRB as in the sterile solution. As the immersion time increases, the open circuit potential first moves negatively and then positively [12]. Meanwhile, under the same immersion time, the open circuit potential in the SRB-containing solution is always negative than that in the sterile solution. In other words, the corrosion tendency of X80 steel

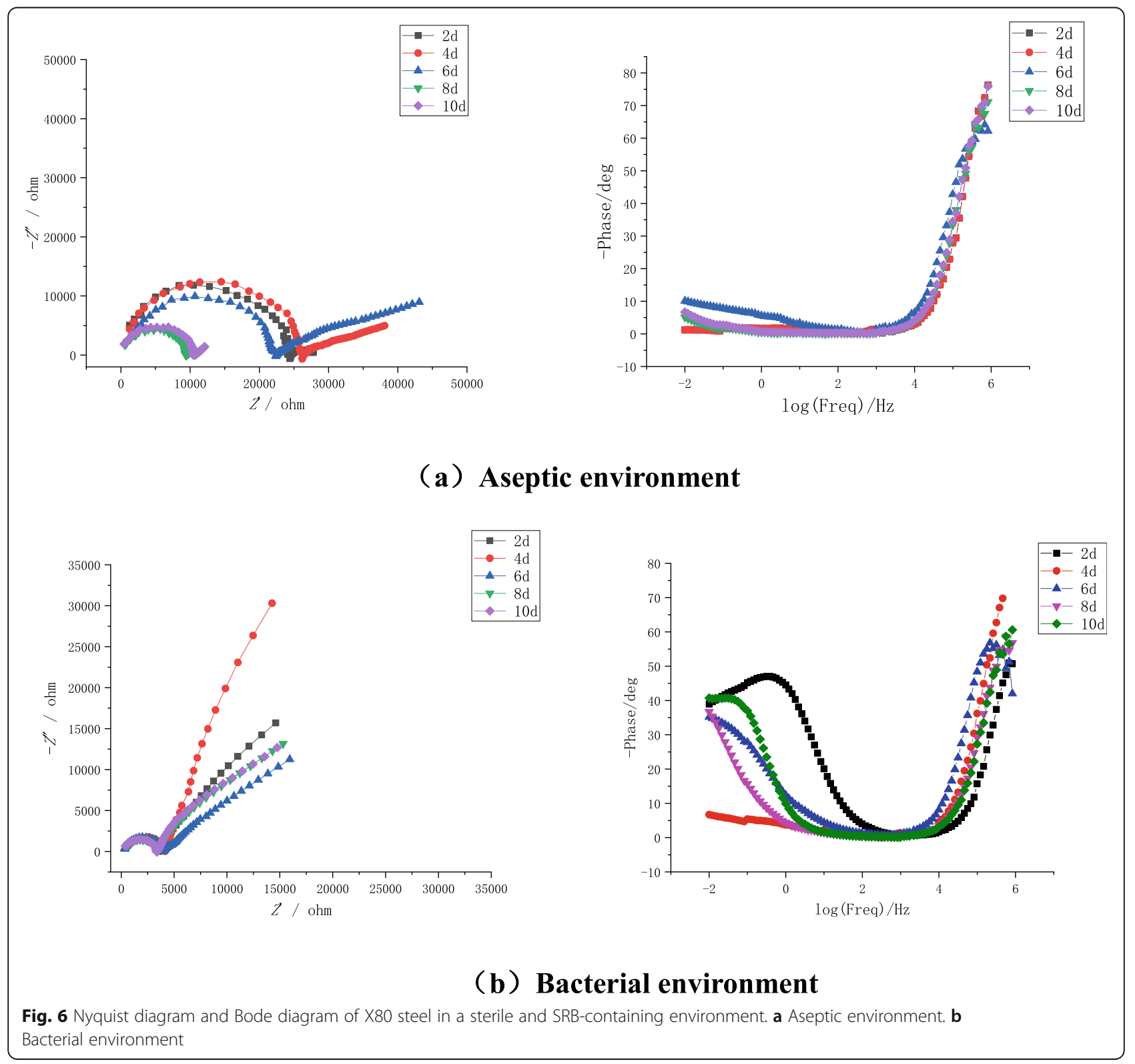




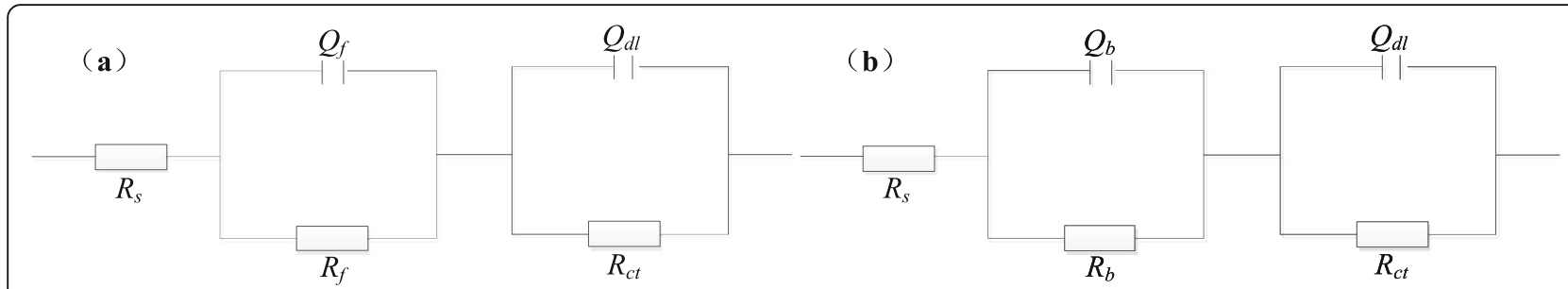

Fig. 7 The equivalent circuits of X80 steel: (a) sterile soil; (b) Soil inoculated with SRB

is increased due to the presence of SRB, and the corrosion tendency reaches the maximum around the 6th day.

The polarization curve of X80 steel after immersion for 5 days and 10 days are shown in Fig. 5 . It can be seen from Fig. 5 that the polarization curve of X80 steel in the solution containing SRB is to the upper left, which indicates that X80 steel has a greater corrosion tendency. The polarization curve was fitted and the corresponding electrochemical parameters are listed in Table 3. It can be seen from Fig. 5 and Table 3 that the corrosion current density of X80 steel in the solution containing SRB is about 7 times that of the sterile environment during the same immersion time, which indicates that SRB greatly promotes corrosion. In addition, the results of the experimental group and the control group showed that the corrosion rate of $\mathrm{X} 80$ steel on the 5th day was lower than that on the 10th day.

In order to further research the effect of SRB on the corrosion behavior of X80 steel in the soil simulation solution, the AC impedance spectrum of X80 steel was measured and the results are shown in Fig. 6. Where $Z^{\prime}$ is the real part of the AC impedance spectrum and $Z^{\prime \prime}$ is the imaginary part [29]. It can be seen from Fig. 6(a) that with the extension of the sample immersion time, both the impedance arc and the capacitive reactance radius of X80 steel show a law that first slightly increases and then gradually decreases. This is because the corrosion product continues to increase over time from the first day to the fourth and its diffusion rate is much lower than the generation, which leads to the accumulation of corrosion product film on the surface of X80 steel, and the corrosion product plays a role in protecting the substrate. From the fourth day to the tenth, as the diffusion rate of the corrosion product increases and the generation rate decreases, the corrosion product film on the metal surface begins to crack or even fall off. This causes harmful ions in the solution to contact the remaining X80 substrate through the gap to form crevice corrosion

Table 4 Fitting results of EIS in sterile soil simulated solutions

\begin{tabular}{llllll}
\hline Time $(\mathbf{d})$ & $\mathbf{R}_{\mathbf{s}}\left(\boldsymbol{\Omega} \cdot \mathbf{c m}^{2}\right)$ & $\mathbf{n}_{\mathbf{f}}$ & $\mathbf{R}_{\mathbf{f}}\left(\mathbf{k} \boldsymbol{\Omega} \cdot \mathbf{c m}^{2}\right)$ & $\mathbf{n}_{\mathbf{d l}}$ & $\mathbf{R}_{\mathbf{c t}}\left(\mathbf{k} \mathbf{\Omega} \cdot \mathbf{c m}^{\mathbf{2}}\right)$ \\
\hline 5 & 626.0 & 0.28 & 12.4 & 0.9287 & 120.8 \\
10 & 460.2 & 0.67 & 10.3 & 0.4337 & 112.1 \\
\hline
\end{tabular}

and accelerate the corrosion rate of the substrate. On the other hand, the combination of $\mathrm{Fe}^{2+}$ and $\mathrm{OH}^{-}$in the solution forms $\mathrm{Fe}(\mathrm{OH})_{2}$, which will form galvanic corrosion with X80 steel to further accelerate the corrosion rate. As SRB continues to increase from the fourth day to the eighth, the impedance arc and capacitive reactance radius of X80 steel gradually decrease, which is a manifestation of the increase in the corrosion rate of the sample caused by the life activity of SRB [30]. From the eighth day to the tenth, SRB formed a dense biofilm on the surface of X80 steel, which caused the corrosion rate of the substrate to decrease. At the same time, the sulfide produced by SRB during growth and metabolism attaches to the gap of the biofilm, which further strengthens the effect of the biofilm on the surface of X80 steel on the diffusion of solution ions [31]. In addition, the presence of straight line is warburg impedance in the high frequency region, which This shows that there is a diffusion control process in the electrochemical corrosion process. According to Fig. 6, it can be found that the impedance radius is significantly smaller in the SRB-containing environment under the same immersion time, which once again proves that X80 steel is more prone to corrosion in the soil containing SRB.

In order to analyze the impedance spectrum in a more intuitive way, ZSimWin software is used to fit the impedance spectrum, where the equivalent circuit is shown in Fig. 7, and the fitting result is shown in Tables 4 and 5 and Fig. 8. Where $R_{s}$ is the resistance of the simulated soil solution, $R_{b}$ and $R_{\mathrm{f}}$ represent the resistance of the corrosion products, $R_{c t}$ represents the charge transfer resistance, $Q_{d l}$ represents the electric double layer capacitance, $Q_{b}$ and $Q_{f}$ represent different meanings, $Q_{b}$ represents the corrosion product film formed capacitive reactance in the sterile soil. While $Q_{f}$ is the capacitive resistance formed under the combined action of microbial film and corrosion product film in the soil of containing SRB. The influence of state variable electrode potential and corrosion

Table 5 Fitting results of ElS in simulated soil solution containing bacteria

\begin{tabular}{llllll}
\hline Time $(\mathbf{d})$ & $\left.\mathbf{R}_{\mathbf{s}}(\boldsymbol{\Omega} \cdot \mathbf{c m})^{2}\right)$ & $\mathbf{n}_{\mathbf{f}}$ & $\mathbf{R}_{\mathbf{b}}\left(\mathbf{k} \boldsymbol{\Omega} \cdot \mathbf{c m}^{2}\right)$ & $\mathbf{n}_{\mathbf{d l}}$ & $\mathbf{R}_{\mathbf{c t}}\left(\mathbf{k} \boldsymbol{\Omega} \cdot \mathbf{c m}^{2}\right)$ \\
\hline 5 & 285.0 & 0.96 & 3.59 & 0.531 & 135.0 \\
10 & 164.8 & 0.71 & 1.48 & 0.981 & 2.999 \\
\hline
\end{tabular}




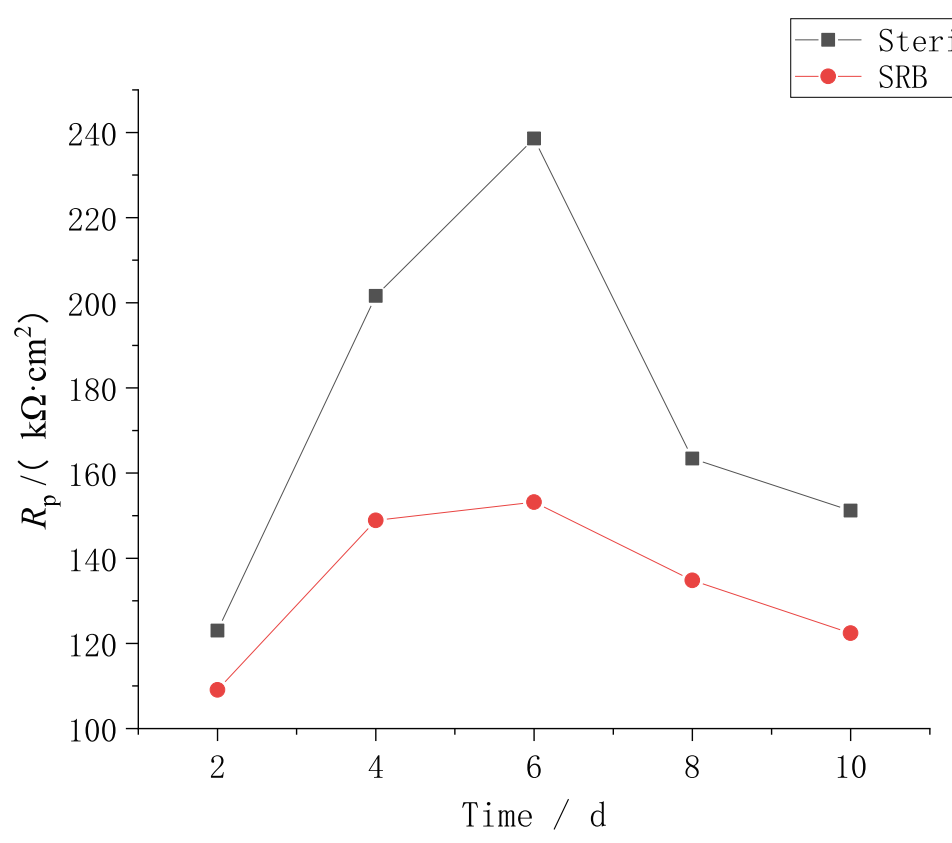

22

Fig. 8 Polarization resistance changes with time of $X 80$ steel in inoculated and uninoculated SRB soil

product layer or biofilm is considered, so the polarization resistance $R_{p}=\left(Z_{F}\right)_{\mathrm{w}=0}=R_{\mathrm{f}}+R_{\mathrm{c} t}$ is used to reflect the corrosion rate of X80 steel in the system [32]. Where $Z_{F}$ is the Faraday impedance of the experimental system, which is equivalent to the impedance of the experimental system after removing the soil simulated solution resistance $R_{\mathrm{s}}$ and the non-Faraday impedance $Z_{N F}$.

It can be seen from Tables 4 and 5 that the presence of SRB will significantly reduce the soil resistance, that is to say, the electrolyte conductivity will increase. On the other hand, $R_{\mathrm{f}}$ is always greater than $R_{\mathrm{b}}$ during the same immersion time, which also shows that the presence of SRB reduces the corrosion resistance of X80 steel in soil. It can be seen from Fig. 8 that the polarization resistance $R_{p}$ of X80 steel in aseptic and SRB-containing soils changes in the same way, which are both increase first and then decrease as the immersion time increases, and the maximum is at the 6th day. This is because the formation rate of corrosion products in the early stage of the experiment is much greater than its diffusion rate, which leads to the gradual accumulation of corrosives on the sample surface, and the formed corrosion

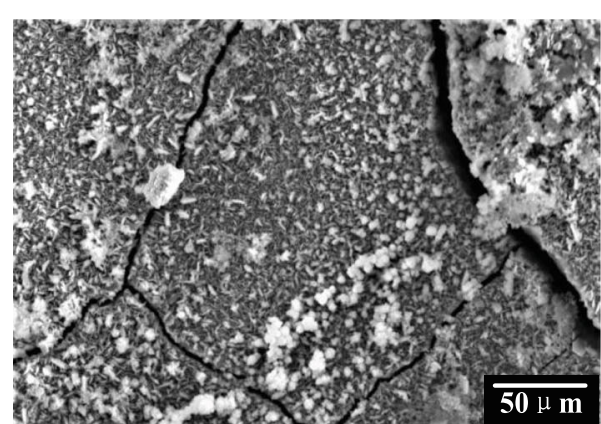

(a) Aseptic environment

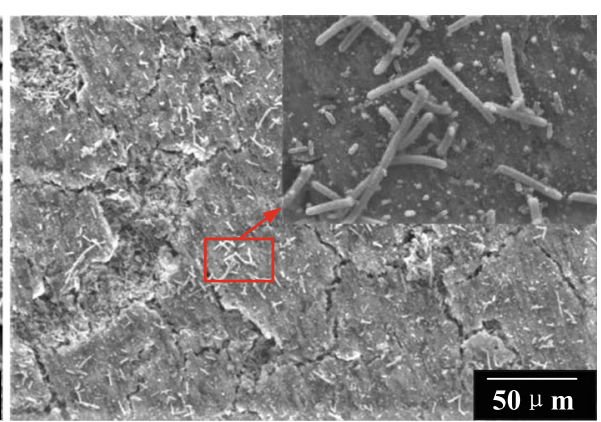

(b) Bacterial environment

Fig. 9 Micro-morphology of corrosion products on the sample surface. Acceleration voltage was 15,000 V, working distance was $7500 \mu \mathrm{m}$, emission current was $159 \mu \mathrm{A}$. a Aseptic soil environment. b Bacterial soil environment 


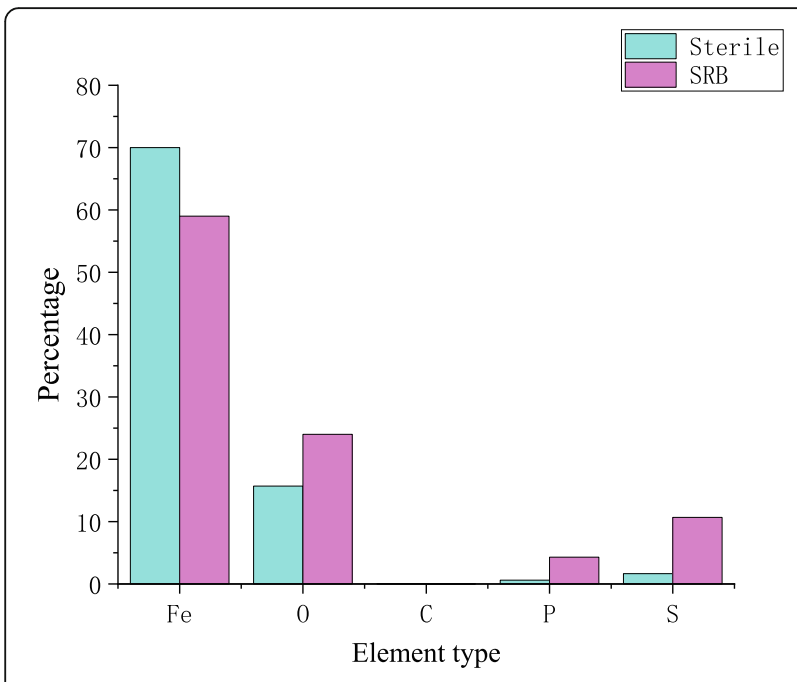

Fig. 10 EDS analysis results of corrosion products in inoculated and uninoculated SRB soil

product film inhibits the corrosion of metals. As the immersion time continues to increase, the corrosion product diffusion rate exceeds its generation rate, and defects such as cracks appear on the corrosion product film, which in turn leads to a decrease in polarization resistance. In addition, SRB also promotes the diffusion of corrosion products, which leads to a smaller $R_{p}$ of the sample in the soil containing SRB. This conclusion indicates that SRB promotes the corrosion of X80 steel, which is consistent with the analysis results of open circuit potential and polarization curve.

\section{Corrosion product morphology and product analysis}

The microscopic morphology of the corrosion products of X80 steel after immersion for ten days is shown in
Fig. 9. The area of Fig. 9 was scanned by EDS, and the result is shown in Fig. 10.

It can be seen from Fig. 9 that after X80 steel is placed in sterile soil for ten days, a small part of the "cotton ball"-like product $\alpha-\mathrm{FeO}(\mathrm{OH})$ and the typical "flowerlike" scale $\gamma$ - $\mathrm{FeO}(\mathrm{OH})$ morphology on the sample surface. In the soil of containing SRB, a large amount of SRB on the surface of the sample was clearly observed, and a dense corrosion product film was formed. It can be seen from Fig. 10 that when SRB is present in the soil, the proportion of iron on the surface of the sample decreases, and the proportion of oxygen, phosphorus and sulfur increases significantly [33]. This is because the corrosion products of $\mathrm{X} 80$ steel in sterile soil are mainly oxidation Iron, while SRB is present in the soil, sulfide of iron and phosphide of iron will be formed on the surface of the sample [7]. Therefore, the cathodic reaction process of the corrosion of X80 steel in SRBcontaining soil is the depolarization reaction of phosphide and sulfide, which further proves that SRB promotes the corrosion of X80 steel [34]. The corrosion mechanism are shown in eqs. (1) to (6), and the specific reaction path is shown in Fig. 11 [3].

$$
\begin{aligned}
& \text { Anode reaction } 4 \mathrm{Fe} \rightarrow 4 \mathrm{Fe}^{2+}+8 \mathrm{e}^{-} \\
& \text {Ionization of water } \quad 8 \mathrm{H}_{2} \mathrm{O} \leftrightarrow 8 \mathrm{H}^{+}+8 \mathrm{OH}^{-} \\
& \text {Cathodic reaction } 8 \mathrm{H}^{+}+8 \mathrm{e}^{-} \rightarrow 8 \mathrm{H} \\
& \text { Cathode reaction with bacteria } \mathrm{SO}_{4}^{2-} \\
& \quad+8 \mathrm{H} \stackrel{\text { SRB }}{\rightarrow} \mathrm{S}^{2-}+4 \mathrm{H}_{2} \mathrm{O} \\
& \text { Primary corrosion products } \mathrm{Fe}^{2+} \\
& \quad+\mathrm{S}^{2-} \rightarrow \mathrm{FeS}
\end{aligned}
$$

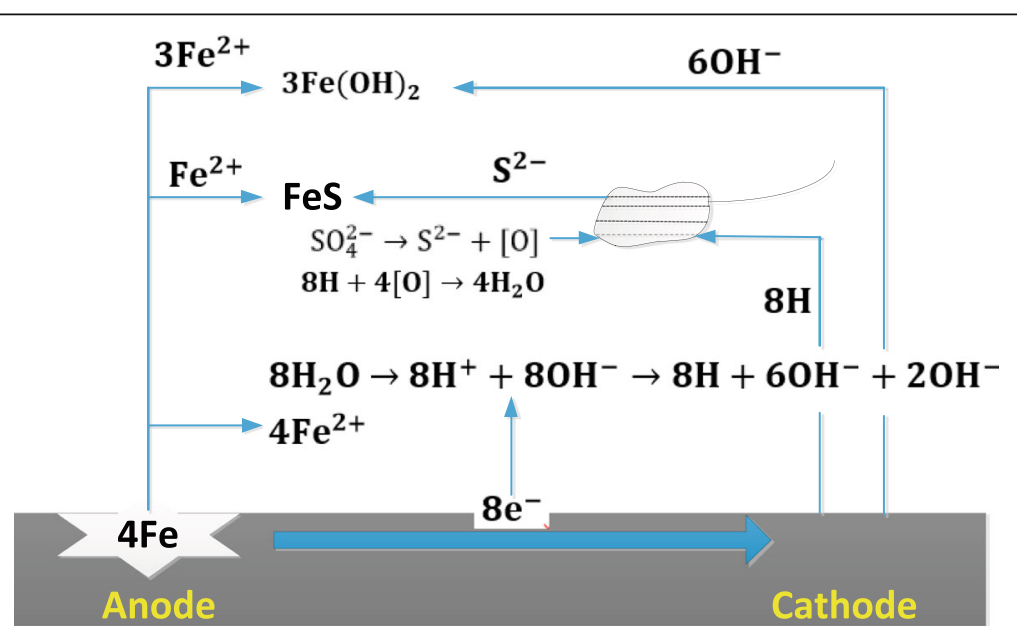

Fig. 11 SRB corrosion diagram 


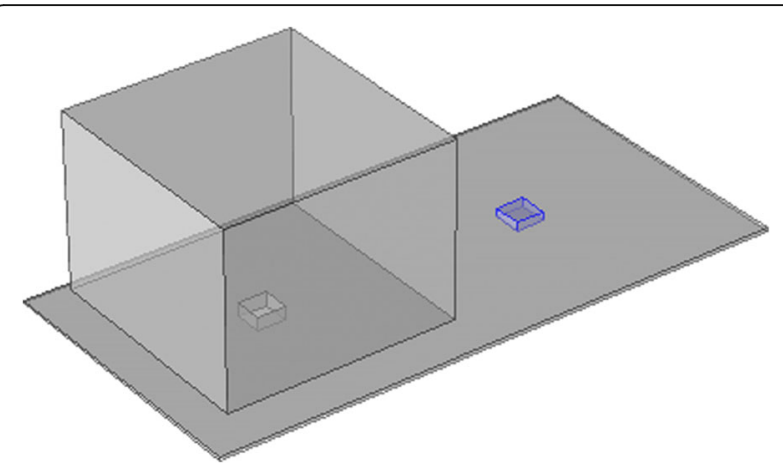

Fig. 12 Corrosion rate of $X 80$ pipeline steel with or without SRB in the soil

Secondary corrosion products $3 \mathrm{Fe}^{2+}$

$$
+6 \mathrm{OH}^{-} \rightarrow 3 \mathrm{Fe}(\mathrm{OH})_{2}
$$

\section{Corrosion weight gain}

The corrosion rate of X80 pipeline steel under the peeling coating in the aseptic and SRB-containing soil was measured and calculated by the weightlessness experiment method. The results are expressed in terms of mass change as shown in Fig. 12. It can be seen from
Fig. 12 that the corrosion rate of X80 steel in SRBcontaining soil is greater than that of aseptic soil in the same time, which indicates that SRB greatly promotes corrosion. In addition, the results of the experimental group and the control group once again showed that the corrosion rate of $\mathrm{X} 80$ steel on the 5th day was lower than that on the 10th day.

\section{Numerical simulation}

The "secondary current distribution and dilute matter transfer" interface were used to simulation and the threedimensional physical model was established as shown in Fig. 12. Arbitrarily take a microcell from the stable, passive corrosion model shown in Fig. 12, its side length are set as $d_{\mathrm{x}}, d_{\mathrm{y}}, d_{\mathrm{z}}$, where the volume $d_{\mathrm{v}}=d_{\mathrm{x}} d_{\mathrm{y}} d_{\mathrm{z}} \neq 0$, and the microcell structure is shown in Fig. 13.

Suppose that the current flowing into the cell in the $x$ direction and the current flowing out in the model are equal, namely:

$$
i_{x} d y d z=\left(i_{x}+\frac{\partial i_{x}}{\partial x} d x\right) d y d z
$$

Similarly, in the $y$ direction:

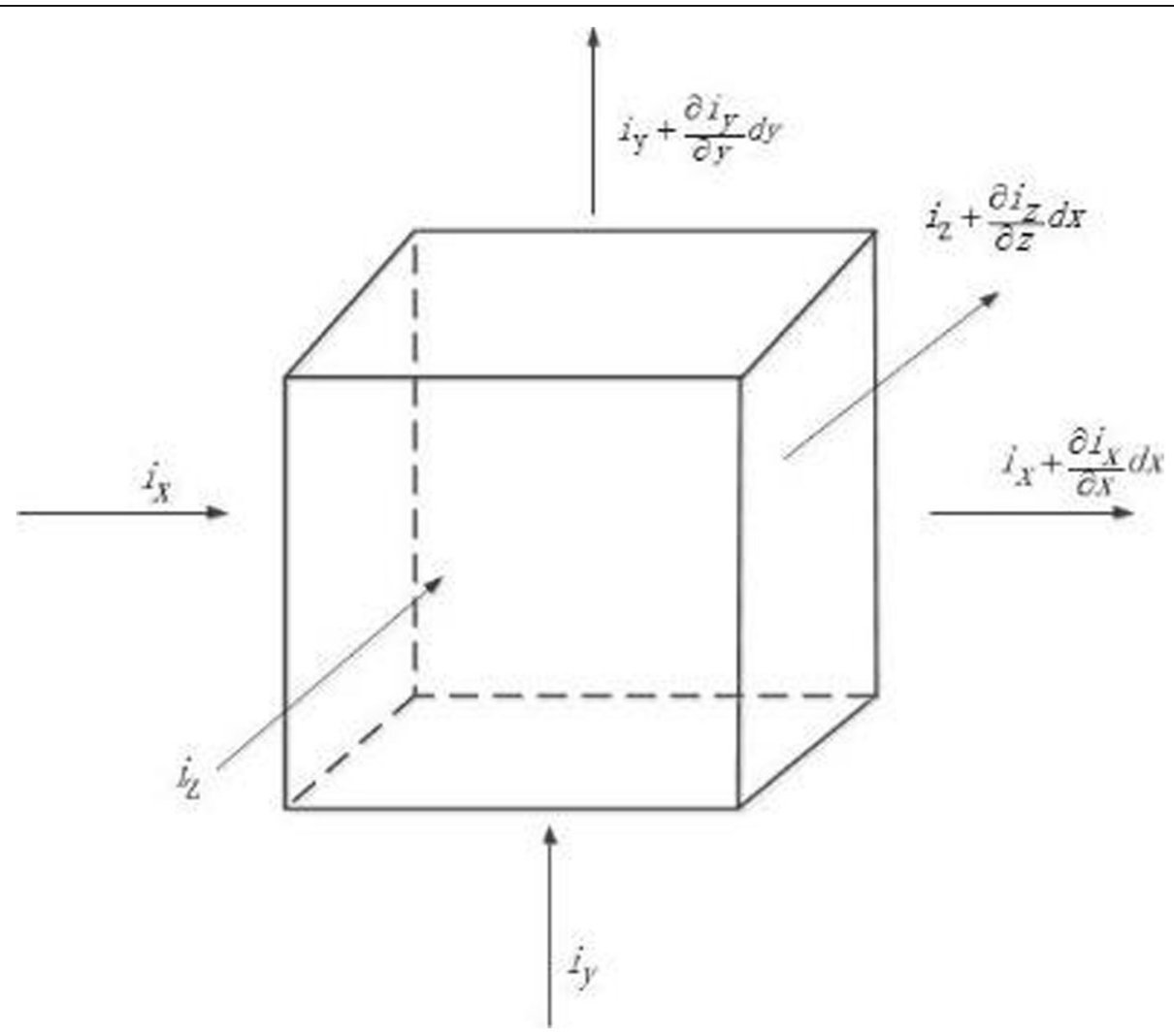

Fig. 13 Schematic diagram of micro-body current flow 


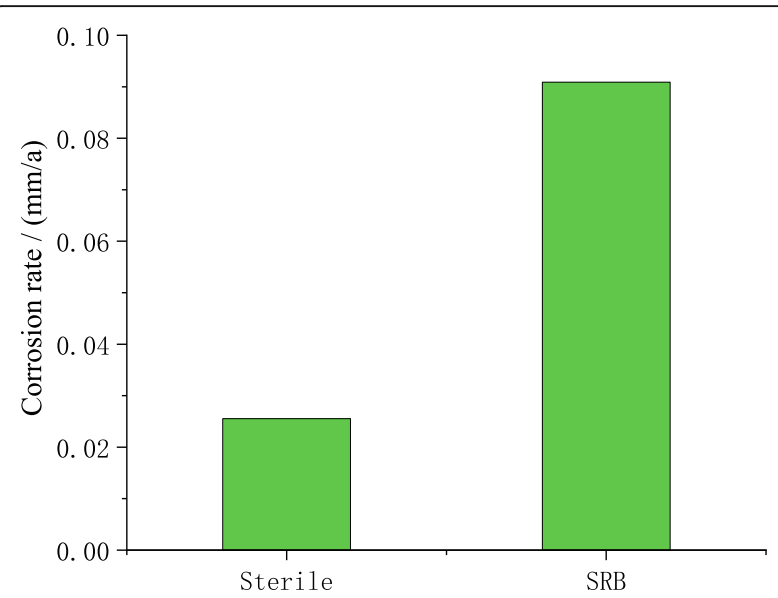

Fig. 14 Corrosion rate of $X 80$ steel

$$
i_{y} d x d z=\left(i_{y}+\frac{\partial i_{y}}{\partial y} d y\right) d x d z
$$

in the $z$ direction:

$$
i_{z} d x d y=\left(i_{z}+\frac{\partial i_{z}}{\partial z} d z\right) d x d y
$$

From the above eqs. (7), (8), (9) we can get:

$$
-\frac{1}{\rho} \nabla^{2} \phi=0
$$

That is to say, the Laplace equation is used as the control equation of the potential distribution in the corrosion field. The surface corrosion rate of X80 steel obtained by simulation calculation after 10 days in soil is shown in Fig. 14. It can be found from Fig. 14 that the maximum corrosion rate of X80 steel in soil containing SRB is about 3.5 times that of sterile soil.

\section{Conclusions}

(1) The growth and reproduction of SRB will cause the $\mathrm{pH}$ of the solution to rise. The open circuit potential change law of X80 steel in aseptic and SRBcontaining soil is basically the same, but the corrosion tendency is greater in SRB-containing soil.

(2) Both the simulation results and the electrochemical experiment results show that SRB promotes the corrosion of X80 steel in the soil. In addition, the simulation results show that the maximum corrosion rate with SRB is about 3.5 times that of sterile soil.

(3) The corrosion products of X80 steel in sterile soil are mainly oxidation of iron, while SRB is present in the soil, sulfide and phosphide of iron will be formed on the surface of the sample

\section{Abbreviations}

SRB: Sulfate-reducing bacteria; SEM: Scanning electron microscope; EDS: Xray energy spectrum; MIC: Microbiologically influenced corrosion;

BCSR: Biocatalytic cathodic sulfate reduction

\section{Acknowledgements}

We would like to thank Dr. Xiaoning Shen for his assistance in the simulation techniques. We also would like to gratefully thank and acknowledge Miss. Bo Shi for the precise storage of SRB.

\section{Authors' contributions}

Conceptualization, QMD; Methodology, YXQ; Software, YXQ and YNG; Validation, YYC, YXQ; Formal analysis, YXQ and YNG; Investigation, QMD; Resources, QMD; Data curation, QMD and YXQ; Writing —original draft preparation, $Y X Q$; Writing — review and editing, YYC, YXQ, QMD, YNG; Funding acquisition, $Y X Q$ and $Y Y C$. All authors consent and approved the final version of the manuscript.

\section{Funding}

This work was supported by 2019 Tianjin Graduate Student Research and Innovation Project (2019YJSS069) and The basic scientific research service fee of the Central University of Civil Aviation University of China (3122019107). The funders had no role in the design of the study and collection, analysis, and interpretation of data and in writing the manuscript.

\section{Availability of data and materials}

All data, raw and processed, is readily available from the corresponding author on request.

\section{Ethics approval and consent to participate}

This research does not involve any ethical issues.

\section{Consent for publication}

Not applicable.

\section{Competing interests}

"The authors declare that there is no conflict of interests regarding the publication of this article."

Received: 2 September 2020 Accepted: 21 December 2020 Published online: 09 January 2021

\section{References}

1. Xie F, Li X, Gao SF, Wang D, Wu M. Research progress on stress corrosion cracking behavior of X80 pipeline steel in soil environment containing sulfate-reducing bacteria. Materials Guide. 2018;31(13):69-77.

2. Chen X, Li SB, Zheng ZS, Xiao JB, Ming NX, Chuan H. Research on microbial corrosion behavior of $X 70$ pipeline steel in Daqing soil environment. J Chin Soc Corrosion Protect. 2020;40(02):175-81.

3. Xu P, Ren HY, Wang CZ, Zhang YJ. Research progress of mixed microbial corrosion and analysis methods on metal surfaces. Surface Technol. 2019; 48(01):216-24.

4. Li X, Sun C. Synergistic effect of Carbamide and sulfate reducing Bacteria on corrosion behavior of carbon steel in soil. Int J Corrosion. 2018;2018: 7491501.1-7491501.14

5. Ubong E, Omar F, Jerzy S. Effect of benzothiazole biocide on SRB-induced biocorrosion of hot-dip galvanized steel. Eng Fail Anal. 2018;93:111-21.

6. Sun FY, Yang X, Lu Y, Shang K. Effects of SRB on microbial corrosion behavior of X100 pipeline steel in saline soil. Pipeline Technol Equipment. 2018;05:42-6.

7. Deyab MA. Efficiency of cationic surfactant as microbial corrosion inhibitor for carbon steel in oilfield saline water [J]. J Mol Liq. 2018;255(1):550-5.

8. Sun FY, Zhao GX, Yang DP. Microbial corrosion characteristics of X100 pipeline steel in Korla soil simulation solution. Materials Guide. 2014;28(24): 47-51.

9. Zhang WY. Advances in marine microbial corrosion research. Comprehensive Corrosion Control. 2017;31(01):8-12.

10. Vaithiyanathan S, Chandrasekaran K, Barik RC. Green biocide for mitigating sulfate-reducing bacteria influenced microbial corrosion. Biotech. 2018;8(12):495.

11. Chilkoor G, Karanam SP, Star S. Hexagonal boron nitride: the thinnest insulating barrier to microbial corrosion. ACS Nano. 2018;12(3):2242-52. 
12. Wu M, Guo ZW, Xie F, Wang D, Wang YC. Research progress on corrosion behavior of pipeline steel under the action of anions and sulfate-reducing bacteria. Materials Guide. 2018;32(19):3435-43.

13. Cui Y, Qin Y, Dilimulati D. The effect of chlorine ion on metal corrosion behavior under the scratch defect of coating[]]. Int Corrosion. 2019;(2019):1-11.

14. Deng PC, Liu QB, Li ZY. Research on the corrosion behavior of X70 pipeline steel in tropical seawater-sea mud transition zone. J Chin Soc Corrosion Protect. 2018;38(05):9-17.

15. Jing $Q$, Liu L, Xie JF, Wang P. Effect of sulfate reducing bacteria on corrosion behavior of Q235 steel in corrosion scale samples of oil pipelines. Corrosion Protection. 2018:39(01):6-10 + 16 .

16. Venzlaff $H$, Stratmann M, Mayrhofer K. Accelerated cathodic reaction in microbial corrosion of iron due to direct electron uptake by sulfatereducing bacteria. Corros Sci. 2013;66(1):88-96.

17. Sheng $X$, Ting YP, Pehkonen SO. The influence of sulphate-reducing bacteria biofilm on the corrosion of stainless steel AISI 316. Corros Sci. 2007;49(5):0-2176.

18. Devatha $C P$, Jagadeesh $K$, Patil M. Effect of green synthesized iron nanoparticles by Azardirachta Indica in different proportions on antibacterial activity. Environ Nanotechnol Monit Manage. 2018;9:85-94.

19. Wikieł AJ, Datsenko I, Vera M. Impact of desulfovibrio alaskensis biofilms on corrosion behaviour of carbon steel in marine environment. Bioelectrochemistry. 2014;97(1):52-60.

20. Venzlaff $H$, Stratmann M, Mayrhofer K. Accelerated cathodic reaction in microbial corrosion of iron due to direct electron uptake by sulfatereducing bacteria [J]. Corros Sci. 2013;66(1):88-96.

21. Enning D, Venzlaff $H$, Garrelfs J. Marine sulfate-reducing bacteria cause serious corrosion of iron under electroconductive biogenic mineral crust []]. Environ Microbiol. 2012;14(7):1772-87.

22. Dong ZH, Shi W, Ruan HM. Heterogeneous corrosion of mild steel under SRB-biofilm characterised by electrochemical mapping technique. Corros Sci. 2011;53(9):0-2987.

23. Castaneda $H$, Benetton XD. SRB-biofilm influence in active corrosion sites formed at the steel-electrolyte interface when exposed to artificial seawater conditions. Corros Sci. 2008;50(4):0-1183.

24. Little BJ, Lee JS, Ray RI. The influence of marine biofilms on corrosion: a concise review. Electrochim Acta. 2008;54(1):2-7.

25. Washizu N, Katada Y, Kodama T. Role of $\mathrm{H} 2 \mathrm{O} 2$ in microbially influenced ennoblement of open circuit potentials for type 316L stainless steel in seawater. Corros Sci. 2004:46(5):0-1300.

26. Qing $Y, B a i Y, X u$ J, et al. Effect of alternating current and sulfate-reducing bacteria on corrosion of X80 pipeline steel in soil-extract solution[J]. Materials. 2019;12(1):44

27. Alabbas FM, Williamson C, Bhola SM. Influence of sulfate reducing bacterial biofilm on corrosion behavior of low-alloy, high-strength steel (API-5L X80). Int Biodeterior Biodegradation. 2013;78:34-42.

28. Antony PJ, Raman RKS, Mohanram R. Influence of thermal aging on sulfatereducing bacteria (SRB)-influenced corrosion behaviour of 2205 duplex stainless steel. Corrosion ence. 2008:50(7):1858-64.

29. Jie Z, Xiaolong LI, Jiangwei W. Influence of calcareous deposit on corrosion behavior of Q235 carbon steel with sulfate-reducing bacteria. J Ocean Univ China. 2018;16(006):1213-9.

30. Liu Q, Li Z, Liu ZY. Effects of H2S/HS on stress corrosion cracking behavior of X100 pipeline steel under simulated sulfate-reducing Bacteria metabolite conditions. J Mater Eng Perform. 2017;26(3):2763-75.

31. Zhao Y, Fu Z, Chen X. Bioremediation process and bioremoval mechanism of heavy metal ions in acidic mine drainage. Chem Res Chin Univ. 2018;34(1):1-6.

32. Yousuf I, Arjmand F, Tabassum S. Design and synthesis of a DNA intercalative half-sandwich organ ruthenium (ii)-chromone complex: cytotoxicity evaluation and topoisomerase la inhibition assay. New J Chem. 2019:43(14):5475-87.

33. Jia $R$, Wang $D$, Jin $P$. Effects of ferrous ion concentration on microbiologically influenced corrosion of carbon steel by sulfate reducing bacterium Desulfovibrio vulgaris. Corrosion ence. 2019:153(JUN):127-37.

34. Wei $W$, Jiang YU, Wang Y. Effect of SRB-zeolite technology on immobilization of lead in soil. Shenzhen Daxue Xuebao (Ligong Ban)/ Journal of Shenzhen University ence and Engineering. 2018;35(6):597.

\section{Publisher's Note}

Springer Nature remains neutral with regard to jurisdictional claims in published maps and institutional affiliations.

Ready to submit your research? Choose BMC and benefit from:

- fast, convenient online submission

- thorough peer review by experienced researchers in your field

- rapid publication on acceptance

- support for research data, including large and complex data types

- gold Open Access which fosters wider collaboration and increased citations

- maximum visibility for your research: over $100 \mathrm{M}$ website views per year

At BMC, research is always in progress.

Learn more biomedcentral.com/submissions 